\title{
Pembentukan Buah dan Perkecambahan Tanaman Jarak Pagar pada Transformasi Langsung Melalui Jalur Tabung Polen
}

\author{
Fruit Set and Germination of Physic Nut \\ on Direct Transformation via Pollen-Tube Pathway
}

\author{
Agus Zainudin ${ }^{1,2}$, Bambang Sapta Purwoko ${ }^{3 *}$, Tri Joko Santoso ${ }^{4}$, Sintho Wahyuning Ardie ${ }^{3}$, dan \\ Trikoesoemaningtyas ${ }^{3}$
}

\author{
${ }^{1}$ Program Studi Pemuliaan dan Bioteknologi Tanaman, Sekolah Pascasarjana, Institut Pertanian Bogor \\ ${ }^{2}$ Program Studi Agroteknologi, Fakultas Pertanian-Peternakan, \\ Universitas Muhammadiyah Malang, Malang 65144, Indonesia \\ ${ }^{3}$ Departemen Agronomi dan Hortikultura, Fakultas Pertanian, Institut Pertanian Bogor \\ (Bogor Agricultural University), Jl. Meranti, Kampus IPB Darmaga, Bogor 16680, Indonesia \\ ${ }^{4}$ Balai Besar Penelitian dan Pengembangan Bioteknologi dan Sumber Daya Genetik Pertanian (BB Biogen) \\ Jl. Tentara Pelajar No. 3A, Bogor 16111, Indonesia
}

Diterima 22 September 2016/Disetujui 27 September 2017

\begin{abstract}
The genetic transformation via pollen-tube pathway in jatropha is the first alternative method that was applied in this plant. The objective of the research was to study fruit set and germination of three genotypes of jatropha following direct transformations via pollen-tube pathways. The research was conducted during April 2014 until January 2015 at jatropa's experimental field, Pasuruan, and at green house of ICABIOGRAD, Bogor. Three genotypes of jatropha i.e., IP3A, IP3P and JcUMM18 were used. In the first experiment, split plot design was used where 3 levels of DNA plasmid concentration as a main plot and 5 levels of stigma-drip time of DNA plasmid as a subplot. In the second experiment randomized block design was used with single factor consisting of 15 combinations of concentration and stigma-drip time of DNA plasmid as treatments and control. The results demonstrated that interaction between concentration and application time of DNA plasmid did not significantly affect fruit and seeds formation of three Jatropha genotypes. Combination of DNA plasmid concentration with time of stigma-drip had significant effect on seed germination rate of IP3A genotype, but not significant on the other variables. The concentration of 0.05-0.5 $\mu \mathrm{g} \mu \mathrm{L}^{-1}$ and application time of DNA plasmid at 1-10 hours after pollination could be applied on jatropha genetic transformation via pollen-tube pathways.
\end{abstract}

Keywords: DNA plasmid, Jatropha curcas, pCAMBIA1301, pollen-tube, stigma-drip

\section{ABSTRAK}

Transformasi genetik melalui jalur tabung polen pada jarak pagar adalah metode alternatif pertama yang diterapkan pada tanaman tersebut. Tujuan dari penelitian ini adalah untuk mempelajari pembuahan dan perkecambahan tiga genotipe tanaman jarak pagar pada transformasi secara langsung melalui jalur tabung polen. Penelitian dilaksanakan pada bulan April 2014 hingga Januari 2015 di kebun percobaan jarak pagar, Pasuruan, dan di rumah kaca BB Biogen, Bogor. Tiga genotipe jarak pagar digunakan yaitu IP3A, IP3P dan JCUMM18. Percobaan pertama disusun dalam rancangan petak terbagi. Tiga taraf konsentrasi DNA plasmid sebagai petak utama dan lima taraf waktu penerapan plasmid DNA sebagai anak petak. Percobaan kedua disusun dalam rancangan kelompok lengkap teracak faktor tunggal dengan 15 kombinasi perlakuan konsentrasi dengan waktu tetes DNA plasmid dan 1 tanaman kontrol. Hasil penelitian menunjukkan bahwa interaksi konsentrasi dan waktu pemberian DNA plasmid tidak berpengaruh nyata terhadap pembentukan buah dan biji tiga genotipe jarak pagar. Kombinasi konsentrasi dan waktu tetes DNA plasmid berpengaruh nyata terhadap saat berkecambahan genotipe IP3A, tetapi tidak berpengaruh nyata terhadap peubah-peubah lain pada perkecambahan ketiga genotipe jarak pagar. Konsentrasi DNA plasmid 0.05-0.5 $\mu \mathrm{g} \mu \mathrm{L}^{-1}$ dan waktu penetesan plasmid 1-10 jam setelah penyerbukan dapat diterapkan pada transformasi genetik jarak pagar melalui jalur tabung polen.

Kata kunci: DNA plasmid, Jatropha curcas, pCAMBIA1301, stigma-drip, tabung polen

\footnotetext{
*Penulis untuk korespondensi. e-mail: bspurwoko@ipb.ac.id
} 


\section{PENDAHULUAN}

Jarak pagar merupakan tanaman potensial penghasil bahan bakar nabati dengan kandungan minyak 35-45\% yang mudah dikonversi menjadi biodiesel, serta sebagai tanaman pengendali erosi (Cholid, 2014) disamping dapat dimanfaatkan untuk keperluan bidang farmasi, kosmetik dan lainnya. Karena itu, upaya peningkatan produksi melalui perbaikan genetik, teknik budidaya dan sistem usaha tani lainnya perlu terus dilakukan. Pengembangan jarak pagar sebagai salah satu sumber bahan bakar nabati masih menghadapi banyak kendala antara lain belum tersedianya varietas yang berproduksi tinggi atau belum menguntungkan bagi petani (Ghosh dan Singh, 2011; Hartati et al., 2012), karena itu, upaya perbaikan genetik perlu terus dilakukan.

Perbaikan genetik tanaman jarak pagar yang dikategorikan sebagai tanaman menyerbuk silang sudah diupayakan melalui berbagai metode pemuliaan konvensional maupun non-konvensional. Perbaikan genetik jarak pagar juga telah berhasil dilakukan melalui pemanfaatan bioteknologi seperti transformasi genetik menggunakan perantara Agrobacterium tumefaciens antara lain transformasi genetik dengan gen $J_{C F A D 2-1}(\mathrm{Qu}$ et al., 2012), gen PaCS (Tistama, 2012) dan gen CrylAb/1 Ac (Gu et al., 2014) maupun gen-gen lain. Transformasi genetik jarak pagar dengan metode yang ada masih menghadapi kendala yaitu rendahnya persentase keberhasilan memperoleh tanaman transgenik dewasa akibat rendahnya keberhasilan pengakaran pada perbanyakan in vitro (Pan et al., 2010; Tistama, 2012). Diperlukan kajian transformasi genetik menggunakan metode alternatif untuk mengatasi hambatan tersebut seperti penerapan metode transformasi genetik secara langsung pada tingkat in vivo dengan memanfaatkan jalur tabung polen. Penerapan transformasi genetik melalui jalur tabung polen juga telah dibuktikan keberhasilan dan efektifitasnya pada tanaman padi (Luo dan Wu, 1988), sorghum (Wang et al., 2007), gandum (Zale et al., 2009), jagung (Yang et al., 2009; Wang et al., 2012), kapas (Zhang et al., 2009; Chen et al., 2010; Bibi et al., 2013), kedelai (Yang et al., 2011), serta berhasil diterapkan untuk meningkatkan keberhasilan hibridisasi antara gandum dan sorgum (Zhang et al., 2012), tetapi penerapan metode tersebut pada tanaman jarak pagar belum dilaporkan.

Tujuan penelitian ini adalah mempelajari pembentukan buah dan perkecambahan tiga genotipe tanaman jarak pagar hasil perlakuan konsentrasi dan waktu penetesan DNA plasmid pada penerapan metode transformasi secara langsung melalui jalur tabung polen.

\section{BAHAN DAN METODE}

\section{Pembentukan Buah dan Biji Tanaman Jarak Pagar pada Transformasi Langsung Menggunakan Plasmid pCAMBIA1301}

Percobaan tahap pertama ini bertujuan untuk memperoleh informasi keberhasilan pembentukan buah dan biji hasil penerapan transformasi langsung pada tiga genotipe tanaman jarak pagar melalui jalur tabung polen dengan perlakuan konsentrasi dan waktu penetesan DNA plasmid pCAMBIA1301. Penelitian ini dilakukan di lahan percobaan jarak pagar Desa Kedungpengaron, Kecamatan Kejayan, Kabupaten Pasuruan pada bulan April hingga Oktober 2014. Tanaman yang digunakan dalam pengujian adalah genotipe IP3A, IP3P dan JcUMM18 yang sudah berumur sekitar 3 tahun. Plasmid yang digunakan adalah pCAMBIA1301 berukuran 11,837 pb yang membawa gen $\beta$ glucuronidase (gus) pengendali terbentuknya warna kebiruan saat bereaksi dengan senyawa X-Gluc dan hygromycinphosphotransferase (hptII) pengendali ketahanan terhadap antibiotik higromisin dengan promotor CaMV 35S. DNA plasmid yang sudah diketahui konsentrasinya $(0.8532 \mu \mathrm{g}$ $\mu \mathrm{L}^{-1}$ ) menggunakan perangkat Nanodrop dilarutkan ke dalam aquades steril untuk mendapatkan konsentrasi sesuai perlakuan.

Rancangan yang digunakan adalah rancangan petak terbagi dengan 3 ulangan. Petak utama berupa konsentrasi DNA plasmid yang terdiri atas 3 taraf, yaitu $0.05 ; 0.25$ dan $0.50 \mu \mathrm{g} \mu \mathrm{L}^{-1}$ (Daud et al., 2009; Bibi et al., 2013); dan anak petak berupa waktu penetesan DNA plasmid pada kepala putik (stigma-drip) terdiri atas 5 taraf, yaitu $\mathrm{W} 1=1$ jam, $\mathrm{W} 2=2 \mathrm{jam}, \mathrm{W} 3=4 \mathrm{jam}, \mathrm{W} 4=7 \mathrm{jam}$, dan $\mathrm{W} 5=10$ jam setelah penyerbukan (Wang dan Ding, 2012). Berdasarkan dua faktor perlakuan tersebut diperoleh sebanyak 15 kombinasi perlakuan dan 45 unit percobaan pada tiap genotipe dari tiga genotipe yang diujikan. Jumlah sampel tiap unit percobaan adalah 10 bunga.

Proses pelaksanaan transformasi secara langsung melalui jalur polen diawali dengan penyerbukan bunga betina tanaman jarak pagar dengan serbuk sari dari genotipe yang sama. Penyerbukan secara manual dilakukan pada pukul 06.30-07.00 WIB, dilanjut dengan pelabelan sesuai perlakuan masing-masing. Kepala putik yang sudah diserbuki ditandai dengan adanya serbuk sari yang menempel merata pada permukaannya ditetesi $2 \mu \mathrm{L}$ DNA plasmid (Shan et al., 2012) sesuai perlakuan konsentrasi dan waktu pemberiannya.

Pengamatan dilakukan terhadap beberapa peubah yang meliputi: umur panen tiap buah, jumlah buah berbiji normal, ukuran diameter dan panjang tiap buah, jumlah biji normal yang terbentuk tiap buah, bobot biji kering tiap buah, dan bobot tiap biji. Data yang diperoleh dianalisis dengan uji $\mathrm{F}$ taraf 5\% dan 1\%, jika menunjukkan pengaruh nyata dilanjutkan uji jarak berganda Duncan taraf 5\%.

\section{Perkecambahan Benih Jarak Pagar Generasi T0 Hasil Transformasi Langsung melalui Jalur Tabung Polen}

Percobaan tahap kedua ini bertujuan untuk memperoleh informasi pengaruh konsentrasi dan waktu penetesan plasmid pada proses transformasi langsung melalui jalur tabung polen terhadap perkecambahan benih tiga genotipe jarak pagar generasi T0.

Bahan tanam yang digunakan berupa benih tanaman jarak pagar generasi T0 (benih yang dihasilkan dari bunga dengan perlakuan penetesan DNA plasmid) dan benih 
kontrol (benih yang dihasilkan dari bunga tanpa perlakuan penetesan DNA plasmid) dari genotipe IP3A, IP3P, dan JcUMM18 hasil percobaan tahap pertama. Penelitian dilakukan di dalam rumah kaca Fasilitas Uji Terbatas Balai Besar Litbang Bioteknologi dan Sumberdaya Genetik Pertanian Bogor pada bulan November 2014 hingga Januari 2015. Pelaksanaan pengujian menggunakan rancangan kelompok lengkap teracak (RKLT) faktor tunggal dengan 16 taraf perlakuan, yaitu 1 kontrol (benih asal tanaman tanpa perlakuan transformasi) dan 15 kombinasi konsentrasi DNA plasmid $0.05,0.25$, dan $0.50 \mu \mathrm{g} \mu \mathrm{L}^{-1}$ dengan waktu tetes 1, 2, 4, 7, dan 10 jam setelah penyerbukan. Tiap perlakuan diulang 3 kali sehingga terdapat 48 unit percobaan. Jumlah benih yang disemai tiap perlakuan (Tabel 4) sesuai jumlah benih yang diperoleh masing-masing unit pada percobaan sebelumnya.

Peubah pengamatan meliputi: saat benih berkecambah dan persentase benih tumbuh (dihitung berdasarkan jumlah benih yang tumbuh dibagi jumlah benih yang disemai dikalikan 100\%). Data persentase benih tumbuh ditransformasi dengan $\log (\mathrm{x}+1)$ sebelum dianalisis. Data yang diperoleh dianalisis dengan uji $\mathrm{F}$ taraf 5\% dan 1\%, jika menunjukkan pengaruh nyata dilanjutkan uji jarak berganda Duncan taraf $5 \%$.

\section{HASIL DAN PEMBAHASAN}

\section{Pembentukan Buah dan Biji Tanaman Jarak Pagar pada Transformasi Langsung Menggunakan Plasmid pCAMBIA1301}

Hasil penelitian ini menunjukkan bahwa interaksi perlakuan konsentrasi dan waktu penetesan DNA plasmid pada kepala putik yang diberikan dengan metode transformasi langsung melalui jalur tabung polen tidak berpengaruh nyata terhadap umur panen, jumlah dan persentase buah yang dipanen, diameter dan panjang buah, jumlah biji per buah, bobot biji per buah serta bobot tiap biji jarak pagar genotipe IP3A, IP3P, dan JcUMM18. Akan tetapi, perlakuan konsentrasi DNA plasmid berpengaruh nyata terhadap persentase buah panen genotipe JcUMM18, sedangkan perlakuan waktu tetes DNA plasmid berpengaruh nyata terhadap persentase buah panen dan bobot biji per buah genotipe IP3A serta panjang buah genotipe JcUMM18 (Tabel 1, 2, dan 3).

Keberhasilan reproduksi tanaman jarak pagar dipengaruhi beberapa faktor antara lain: keguguran bunga betina, pembentukan biji yang relatif rendah, fertilitas bunga betina rendah, sangat jarangnya penyerbukan sendiri karena sifat berkelamin tunggal, keberadaan faktor penyerbuk, tertundanya periode reseptif stigma, dan diferensiasi morfologi stigma reseptif untuk penerimaan serbuk sari yang tepat (Bhattacharya et al., 2005). Perbedaan tipe penyerbukan juga tidak menyebabkan perbedaan pada keberhasilan pembentukan buah jarak pagar (Abdelgadir et al., 2012).

Umur panen buah jarak pagar genotipe IP3A, IP3P dan JcUMM18 pada penelitian transformasi ini berturutturut berkisar antara 51.9-54.7, 48.2-53.4, dan 52.5-59.0 hari setelah penyerbukan (Tabel 1). Umur panen tersebut relatif sama dengan yang dilaporkan peneliti jarak pagar lain yaitu 40-50 hari setelah pembuahan (Hasnam, 2006) atau rata-rata 48.2 hari setelah pembuahan (Pranesh et al., 2010). Hal tersebut membuktikan bahwa perlakuan penetesan DNA plasmid pada kepala putik yang sudah diserbuki pada penerapan metode transformasi langsung melalui jalur tabung polen tidak mengganggu proses pembuahan sehingga buah jarak pagar dapat terbentuk dan dipanen pada kisaran umur panen yang relatif sama dengan umur panen buah jarak pagar tanpa perlakuan transformasi yang dilaporkan beberapa peneliti lain.

Konsentrasi DNA plasmid $0.50 \mu \mathrm{g} \mu \mathrm{L}^{-1}$ menyebabkan persentase buah panen paling banyak yaitu $82.0 \%$ pada genotipe JcUMM. Waktu petetesan DNA plasmid pada 7 dan 10 jam dari saat penyerbukan menyebabkan persentase buah panen genotipe IP3A yang lebih banyak, yaitu 87.8 dan

Tabel 1. Umur panen dan persentase buah tanaman jarak pagar genotipe IP3A, IP3P dan JcUMM18 pada transformasi langsung melalui jalur tabung polen dengan perlakuan konsentrasi dan waktu tetes plasmid pCAMBIA1301

\begin{tabular}{|c|c|c|c|c|c|c|}
\hline \multirow{2}{*}{$\begin{array}{l}\text { Konsentrasi } \\
\text { plasmid }\left(\mu g \mathrm{~L}^{-1}\right)\end{array}$} & \multicolumn{3}{|c|}{ Umur panen (HSP) } & \multicolumn{3}{|c|}{ Persentase buah (\%) } \\
\hline & IP3A & IP3P & JcUMM18 & IP3A & IP3P & JcUMM18 \\
\hline 0.05 & 53.8 & 50.4 & 55.1 & 73.3 & 71.3 & $68.7 b$ \\
\hline 0.25 & 52.8 & 49.6 & 55.4 & 70.0 & 68.0 & $75.3 \mathrm{ab}$ \\
\hline 0.50 & 52.7 & 51.9 & 52.7 & 72.7 & 68.0 & $82.0 \mathrm{a}$ \\
\hline \multicolumn{7}{|l|}{ Waktu (JSP) } \\
\hline 1 & 52.0 & 51.1 & 53.3 & 73.3ab & 72.2 & 78.9 \\
\hline 2 & 54.7 & 51.6 & 54.5 & $53.3 \mathrm{~b}$ & 65.6 & 71.1 \\
\hline 4 & 51.9 & 48.9 & 52.5 & $70.0 \mathrm{ab}$ & 68.9 & 72.2 \\
\hline 7 & 53.4 & 53.4 & 59.0 & $87.8 \mathrm{a}$ & 77.8 & 78.9 \\
\hline 10 & 53.6 & 48.2 & 52.9 & $75.6 \mathrm{a}$ & 61.1 & 75.6 \\
\hline
\end{tabular}

Keterangan: Angka-angka dengan notasi sama pada masing-masing peubah, genotipe dan perlakuan menunjukkan tidak nyata perbedaannya berdasarkan uji jarak berganda Duncan $\alpha=0.05$; JSP $=$ jam setelah penyerbukan; HSP $=$ hari setelah penyerbukan 
75.6\% dibandingkan pada waktu penetesan lainnya (Tabel 1). Meskipun demikian, kisaran persentase buah panen antara 53.3-87.8\% pada penelitian transformasi melalui jalur tabung polen ini dibandingkan beberapa penelitian lain yang bukan transformasi menunjukkan bahwa perlakuan transformasi melalui jalur tabung polen tidak berpengaruh negatif terhadap pembuahan jarak pagar IP3A, IP3P, dan JcUMM18. Divakara et al. (2009) pada penelitian bukan transformasi menjelaskan bahwa persentase pembentukan buah jarak pagar akibat penyerbukan sendiri secara buatan, penyerbukan silang buatan dan penyerbukan silang alami secara berurutan adalah $87.9 \%, 86.7 \%$, dan $76.4 \%$.

Perlakuan konsentrasi dan waktu penetesan DNA plasmid pada penerapan metode transformasi langsung melalui jalur tabung polen ini tidak menyebabkan perbedaan nyata terhadap ukuran buah yang dipanen, kecuali panjang buah jarak pagar genotipe JcUMM18 pada perlakuan waktu tetes DNA plasmid (Tabel 2). Buah terpanjang (2.88 $\mathrm{cm})$ diperoleh pada perlakuan waktu tetes 1 jam setelah penyerbukan pada JcUMM18. Kisaran diameter (2.38-2.70 $\mathrm{cm})$ dan panjang buah $(2.50-2.88 \mathrm{~cm})$ jarak pagar pada penelitian ini relatif sama dengan ukuran buah jarak yang dilaporkan beberapa peneliti lain yang tidak menerapkan transformasi genetik. Ukuran buah 30 aksesi jarak pagar dari Indonesia dan beberapa negara lain yang dilaporkan Surahman et al. (2009) yakni berkisar antara 2.5-3.0 cm atau rata-rata $2.76 \mathrm{~cm}$. Ye et al. (2009) juga melaporkan bahwa buah jarak pagar yang diamati di Cina mencapai lebar 2.5$3.0 \mathrm{~cm}$ dan panjang $3-4 \mathrm{~cm}$. Perbedaan ukuran buah tersebut lebih banyak dipengaruhi oleh perbedaan genotipe.

Perlakuan konsentrasi dan waktu tetes plasmid pada transformasi langsung melalui jalur tabung polen juga tidak berpengaruh nyata terhadap jumlah biji per buah, bobot biji per buah serta bobot tiap biji jarak pagar genotipe IP3A, IP3P, dan JcUMM18, kecuali perlakuan waktu tetes plasmid terhadap bobot biji per buah genotipe IP3A. Waktu tetes plasmid 2 dan 10 jam dari saat penyerbukan menyebabkan bobot biji per buah IP3A yang lebih berat, yaitu 1.45 dan
$1.47 \mathrm{~g}$ (Tabel 3). Kisaran jumlah biji, bobot biji per buah dan bobot tiap biji dari genotipe IP3A, IP3P, dan JcUMM18 pada penelitian ini relatif sama dengan kisaran ukuran dan bobot biji beberapa genotipe lain pada penelitian bukan transformasi (Achten et al., 2010; Negussie et al., 2013; Nietsche et al., 2014; Novita et al., 2014; Parwata et al., 2014; Surahman et al., 2009). Perbedaan jumlah, ukuran dan bobot biji tersebut dipengaruhi oleh perbedaan genotipe, sedangkan perlakuan transformasi melalui jalur tabung polen tidak berpengaruh nyata.

\section{Perkecambahan Benih Jarak Pagar Hasil Perlakuan Penetesan DNA Plasmid di Kepala Putik pada Penerapan Metode Transformasi Langsung}

Kemampuan berkecambah benih tanaman jarak pagar bervariasi diantara morfotipe, dengan kata lain faktor genetik banyak mempengaruhi perkecambahan tersebut meskipun faktor lingkungan juga berperan (Padonou et al., 2014). Penetesan DNA plasmid pada kepala putik yang diterapkan di metode transformasi langsung melalui jalur tabung polen tidak berpengaruh nyata terhadap hampir semua peubah perkecambahan tanaman jarak pagar genotipe IP3A, IP3P, dan JcUMM18 kecuali saat berkecambah pada genotipe IP3A (Tabel 3). Saat berkecambah benih genotipe IP3A paling lama yaitu 11.6 hari setelah semai ditemukan pada benih yang diperoleh dari perlakuan penetesan DNA plasmid pCAMBIA1301 konsentrasi $0.5 \mu \mathrm{g} \mu \mathrm{L}^{-1}$ dengan waktu tetes 7 jam setelah penyerbukan. Hal tersebut bisa terjadi karena viabilitas benihnya rendah akibat perubahan metabolisme di dalam benih tersebut (Moncaleano-Escandon et al., 2013). Perubahan metabolisme mungkin terjadi akibat terjadinya penyisipan gen asing pada area fungsional genom tanaman. Berkenaan dengan tujuan pemuliaan, idealnya tanaman transgenik berisi satu salinan utuh dari transgen yang diinginkan yang tersisipkan ke dalam area non fungsional dari genom tanaman, tanpa perubahan lebih lanjut dari DNA tanaman target. Namun, dengan menggunakan teknik

Tabel 2. Diameter buah dan panjang buah tanaman jarak pagar genotipe IP3A, IP3P dan JcUMM18 pada transformasi langsung melalui jalur tabung polen dengan perlakuan konsentrasi dan waktu tetes plasmid pCAMBIA1301

\begin{tabular}{|c|c|c|c|c|c|c|}
\hline \multirow{2}{*}{$\begin{array}{l}\text { Konsentrasi plasmid } \\
\left(\mu \mathrm{g} \mu \mathrm{L}^{-1}\right)\end{array}$} & \multicolumn{3}{|c|}{ Diameter buah $(\mathrm{cm})$} & \multicolumn{3}{|c|}{ Panjang buah $(\mathrm{cm})$} \\
\hline & IP3A & IP3P & JcUMM18 & IP3A & IP3P & JcUMM18 \\
\hline 0.05 & 2.51 & 2.42 & 2.68 & 2.66 & 2.56 & 2.79 \\
\hline 0.25 & 2.54 & 2.45 & 2.70 & 2.71 & 2.74 & 2.80 \\
\hline 0.50 & 2.51 & 2.43 & 2.65 & 2.72 & 2.57 & 2.77 \\
\hline \multicolumn{7}{|l|}{ Waktu (JSP) } \\
\hline 1 & 2.58 & 2.48 & 2.75 & 2.77 & 2.65 & $2.88 \mathrm{a}$ \\
\hline 2 & 2.56 & 2.44 & 2.66 & 2.69 & 2.83 & $2.78 \mathrm{abc}$ \\
\hline 4 & 2.51 & 2.38 & 2.64 & 2.68 & 2.50 & $2.69 \mathrm{c}$ \\
\hline 7 & 2.39 & 2.45 & 2.67 & 2.59 & 2.57 & $2.85 \mathrm{ab}$ \\
\hline 10 & 2.57 & 2.39 & 2.66 & 2.75 & 2.56 & $2.74 \mathrm{bc}$ \\
\hline
\end{tabular}

Keterangan: Angka-angka dengan notasi sama pada masing-masing peubah, genotipe dan perlakuan menunjukkan tidak nyata perbedaannya berdasarkan uji jarak berganda Duncan $\alpha=0.05$; JSP $=$ jam setelah penyerbukan 
Tabel 3. Jumlah biji per buah, bobot biji per buah dan bobot tiap biji tanaman jarak pagar genotipe IP3A, IP3P dan JcUMM18 pada transformasi langsung melalui jalur tabung polen dengan perlakuan konsentrasi dan waktu tetes plasmid pCAMBIA1301

\begin{tabular}{|c|c|c|c|c|c|c|c|c|c|}
\hline \multirow{2}{*}{$\begin{array}{l}\text { Konsentrasi } \\
\left(\mu \mathrm{g} \mu \mathrm{L}^{-1}\right)\end{array}$} & \multicolumn{3}{|c|}{ Jumlah biji per buah } & \multicolumn{3}{|c|}{ Bobot biji per buah (g) } & \multicolumn{3}{|c|}{ Bobot tiap biji (g) } \\
\hline & IP3A & IP3P & JcUMM18 & IP3A & IP3P & JcUMM18 & IP3A & IP3P & JcUMM18 \\
\hline 0.05 & 2.3 & 2.3 & 2.4 & 1.31 & 1.31 & 1.51 & 0.56 & 0.57 & 0.64 \\
\hline 0.25 & 2.4 & 2.4 & 2.5 & 1.38 & 1.31 & 1.56 & 0.58 & 0.55 & 0.64 \\
\hline 0.50 & 2.4 & 2.4 & 2.5 & 1.41 & 1.35 & 1.46 & 0.62 & 0.58 & 0.61 \\
\hline \multicolumn{10}{|l|}{ Waktu (JSP) } \\
\hline 1 & 2.3 & 2.3 & 2.6 & $1.35 \mathrm{ab}$ & 1.32 & 1.61 & 0.56 & 0.58 & 0.63 \\
\hline 2 & 2.5 & 2.3 & 2.4 & $1.45 \mathrm{a}$ & 1.24 & 1.52 & 0.6 & 0.56 & 0.63 \\
\hline 4 & 2.3 & 2.5 & 2.5 & $1.38 \mathrm{ab}$ & 1.37 & 1.39 & 0.59 & 0.53 & 0.58 \\
\hline 7 & 2.3 & 2.3 & 2.4 & $1.18 \mathrm{~b}$ & 1.33 & 1.65 & 0.57 & 0.56 & 0.72 \\
\hline 10 & 2.4 & 2.4 & 2.4 & $1.47 \mathrm{a}$ & 1.37 & 1.37 & 0.62 & 0.58 & 0.59 \\
\hline
\end{tabular}

Keterangan: Angka-angka dengan notasi sama pada masing-masing peubah dan perlakuan menunjukkan tidak nyata perbedaannya berdasarkan uji jarak berganda Duncan $\alpha=0.05 ; \mathrm{JSP}=$ jam setelah penyerbukan

transformasi tanaman saat ini, situs penyisipan transgen tidak terjadi secara acak. Penyisipan T-DNA pada area fungsional dari genom tanaman dapat mengganggu atau mengubah fungsi atau ekspresi gen yang terlibat dalam semua aspek biologi tanaman target (Wilson et al., 2006). Hasil penelitian ini juga menunjukkan bahwa saat berkecambah benih jarak pagar hasil perlakuan transformasi langsung ini tidak selalu konsisten dipengaruhi oleh kombinasi konsentrasi dengan

Tabel 4. Jumlah benih disemai, saat berkecambah dan persentase tumbuh tanaman jarak pagar IP3A, IP3P dan JcUMM18 pada transformasi langsung melalui jalur tabung polen

\begin{tabular}{lccccccccc}
\hline \multirow{2}{*}{ Perlakuan } & \multicolumn{3}{c}{ Jumlah benih disemai } & \multicolumn{2}{c}{ Saat berkecambah (HSS) } & \multicolumn{3}{c}{ Persentase tumbuh (\%) $)^{\text {tr }}$} \\
\cline { 2 - 9 } Kontrol & IP3A & IP3P & JcUMM18 & IP3A & IP3P & JcUMM18 & IP3A & IP3P & JcUMM18 \\
K1W1 & 20.7 & 21.7 & 21.0 & $7.5 \mathrm{~b}$ & 10.0 & 8.6 & 56.7 & 41.2 & 67.1 \\
K1W2 & 18.7 & 19.0 & 20.0 & $8.8 \mathrm{~b}$ & 9.0 & 9.9 & 49.8 & 62.6 & 70.5 \\
K1W3 & 19.3 & 17.0 & 15.0 & $8.5 \mathrm{~b}$ & 8.5 & 9.3 & 34.6 & 70.9 & 61.3 \\
K1W4 & 19.0 & 17.0 & 14.0 & $8.1 \mathrm{~b}$ & 8.1 & 9.7 & 78.9 & 56.8 & 60.2 \\
K1W5 & 16.0 & 22.3 & 15.3 & $9.2 \mathrm{~b}$ & 7.6 & 8.9 & 68.0 & 66.0 & 74.2 \\
K2W1 & 15.0 & 18.3 & 15.7 & $8.0 \mathrm{~b}$ & 8.3 & 11.1 & 76.0 & 60.8 & 53.3 \\
K2W2 & 19.7 & 18.3 & 19.3 & $7.5 \mathrm{~b}$ & 7.6 & 8.9 & 57.6 & 58.7 & 80.7 \\
K2W3 & 15.7 & 16.0 & 15.3 & $8.8 \mathrm{~b}$ & 8.5 & 8.7 & 64.1 & 46.0 & 78.8 \\
K2W4 & 18.3 & 19.7 & 19.0 & $7.8 \mathrm{~b}$ & 7.8 & 7.9 & 85.2 & 68.9 & 71.7 \\
K2W5 & 20.0 & 22.0 & 17.0 & $7.6 \mathrm{~b}$ & 8.6 & 9.4 & 65.8 & 52.2 & 53.9 \\
K3W1 & 19.7 & 16.0 & 19.3 & $8.2 \mathrm{~b}$ & 7.3 & 9.4 & 65.3 & 80.2 & 57.9 \\
K3W2 & 19.7 & 19.0 & 16.0 & $7.5 \mathrm{~b}$ & 8.7 & 11.0 & 62.5 & 90.5 & 63.4 \\
K3W3 & 19.7 & 19.3 & 18.3 & $8.5 \mathrm{~b}$ & 8.4 & 8.5 & 56.0 & 63.7 & 53.4 \\
K3W4 & 21.7 & 19.0 & 16.0 & $11.6 \mathrm{a}$ & 7.9 & 7.9 & 26.7 & 89.6 & 89.8 \\
K3W5 & 14.3 & 18.0 & 22.0 & $8.0 \mathrm{~b}$ & 9.1 & 8.4 & 76.7 & 63.3 & 55.5 \\
\hline
\end{tabular}

Keterangan: Angka-angka dengan notasi yang sama pada masing-masing peubah menunjukkan tidak nyata perbedaanya berdasarkan uji jarak berganda Duncan $\alpha=0.05$; HSS = hari setelah disemai; $\operatorname{tr}=$ analisis terhadap data yang ditransformasi dengan $\log (\mathrm{x}+1)$; Kontrol $=$ benih asal tanaman tanpa perlakuan, $\mathrm{K} 1=$ pCAMBIA1301 konsentrasi $0.05 \mu \mathrm{g} \mu \mathrm{L}^{-1}$, K2 $=$ pCAMBIA1301 konsentrasi $0.25 \mu \mathrm{g} \mu \mathrm{L}^{-1}, \mathrm{~K} 3=$ pCAMBIA1301 konsentrasi $0.50 \mu \mathrm{g} \mu \mathrm{L}^{-1}, \mathrm{~W} 1=$ penetesan 1 jam setelah penyerbukan, W2= penetesan 2 jam setelah penyerbukan, $\mathrm{W} 3=$ penetesan 4 jam setelah penyerbukan, $\mathrm{W} 4=$ penetesan 7 jam setelah penyerbukan, W5 = penetesan 10 jam setelah penyerbukan 
waktu penetesan DNA plasmid. Konsentrasi DNA plasmid yang lebih pekat dengan waktu penetesan yang lebih lama dari saat penyerbukan tidak selalu menyebabkan benih yang diperoleh berkecambah lebih cepat maupun lebih lambat (Tabel 4).

Jumlah benih yang disemai, saat berkecambah, jumlah benih tumbuh dan persentase benih tumbuh tanaman jarak pagar hasil perlakuan penetesan DNA plasmid pada penerapan metode transformasi langsung (benih generasi T0) dalam penelitian ini relatif sama dengan benih kontrol (benih yang dihasilkan dari bunga tanpa perlakuan penetesan DNA plasmid) pada masing-masing genotipe IPA3, IP3P, dan JcUMM18. Keragaan morfologi kecambah benih generasi T0 genotipe IP3A, IP3P, dan JcUMM18 juga relatif sama dibanding dengan kontrol masing-masing (Gambar 1). Hasil tersebut relatif sama dengan laporan peneliti lain bahwa persentase dan saat berkecambah benih jarak pagar non transgenik berturut-turut $65.3 \%$ dan 5.5 hari setelah semai (Moncaleano-Escandon et al., 2013). Perkecambahan pada kondisi lingkungan yang terkontrol dari beberapa
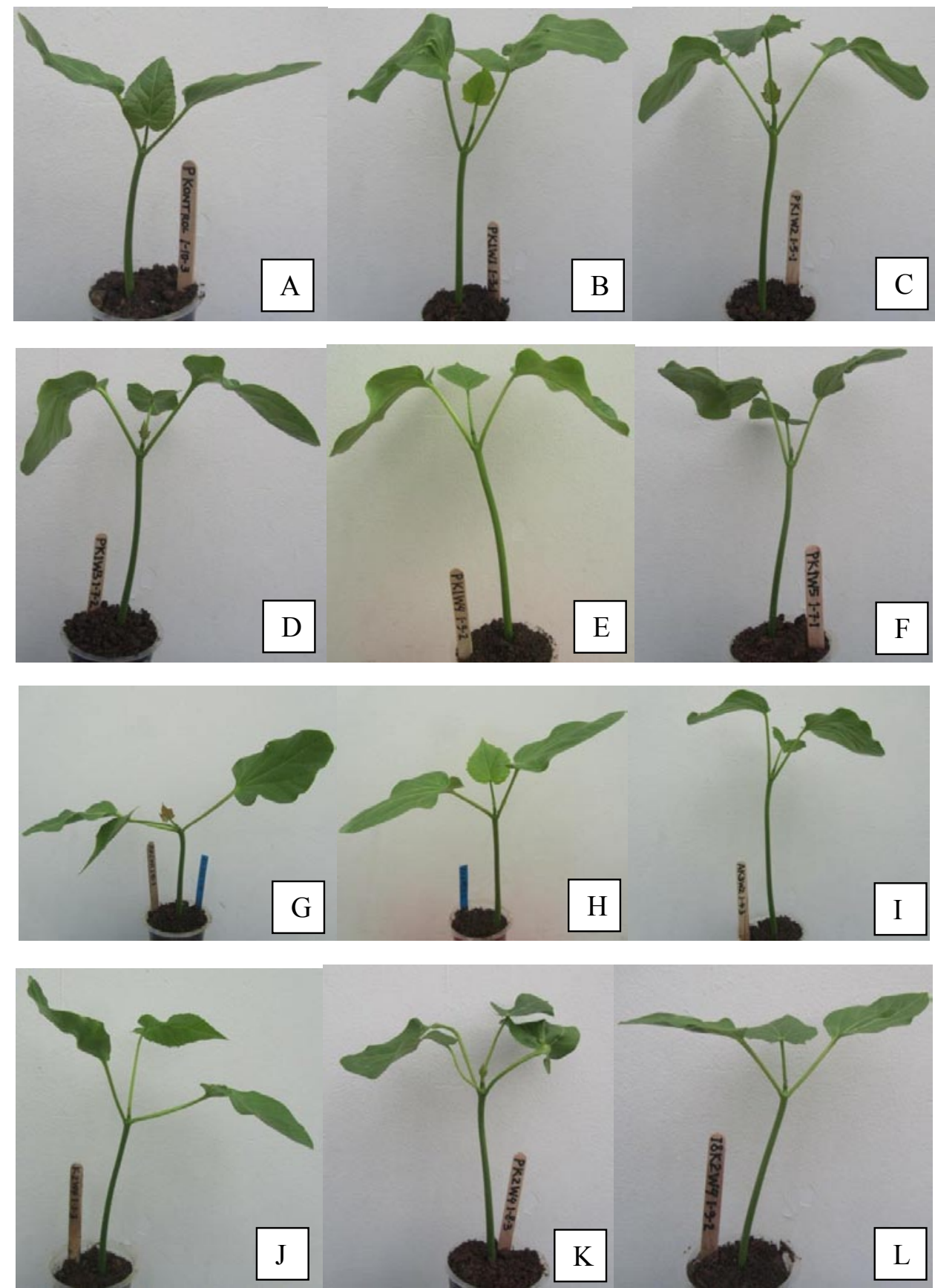

Gambar 1. Bibit jarak pagar generasi T0 hasil perlakuan konsentrasi dan waktu tetes DNA plasmid pada penerapan transformasi langsung melalui jalur tabung polen. $\mathrm{A}=$ jarak pagar tanpa perlakuan (kontrol); B-F = bibit jarak pagar T0 hasil perlakuan penetesan DNA plasmid pada waktu 1, 2, 4, 7, 10 jam setelah penyerbukan; G-I = bibit jarak pagar T0 hasil perlakuan penetesan DNA plasmid konsentrasi $0.05,0.25,0.5 \mu \mathrm{g} \mu \mathrm{L}^{-1}$; J-L = bibit jarak pagar IP3A, IP3P, JCUMM18 generasi T0 hasil perlakuan penetesan DNA plasmid pada konsentrasi dan waktu yang sama 
morfotipe jarak pagar berkisar 50-89\%. Hal tersebut membuktikan bahwa perbedaan perkecambahan benih jarak pagar dipengaruhi oleh vigor benih masing-masing genotipe (Padonou et al., 2014).

\section{KESIMPULAN}

Interaksi antara perlakuan konsentrasi dan waktu tetes DNA plasmid pCAMBIA1301 pada transformasi langsung melalui jalur tabung polen tidak berpengaruh nyata terhadap pembentukan buah dan biji tanaman jarak pagar genotipe IP3A, IP3P, dan JcUMM18. Pengaruh nyata hanya ditemukan pada perlakuan konsentrasi DNA plasmid terhadap persentase buah panen JcUMM18, perlakuan waktu tetes DNA plasmid terhadap persentase buah panen dan bobot biji per buah IP3A, serta panjang buah JcUMM18. Perlakuan kombinasi konsentrasi dengan waktu penetesan DNA plasmid tidak berpengaruh nyata terhadap hampir semua peubah perkecambahan yang diamati, kecuali terhadap saat berkecambah IP3A. Konsentrasi DNA plasmid 0.05-0.5 $\mu \mathrm{g} \mu \mathrm{L}^{-1}$ dan waktu penetesan 1-10 jam setelah penyerbukan dapat diterapkan pada transformasi genetik tanaman jarak pagar melalui jalur tabung polen.

\section{UCAPAN TERIMA KASIH}

Ucapan terima kasih disampaikan kepada DIKTI yang telah memberikan Beasiswa BPPS (BPP-DN) Tahun 20122014 serta BB Biogen atas penyediaan bahan, peralatan, laboratorium molekuler dan fasilitas LUT.

\section{DAFTAR PUSTAKA}

Abdelgadir, H.A., S.D. Johnson, J. Van Staden. 2012. Pollen viability, pollen germination and pollen tube growth in the biofuel seed crop Jatropha curcas (Euphorbiaceae). South African J. Bot. 79:132-139.

Achten, W.M.J., L.R. Nielsen, R. Aerts, A.G. Lengkeek, E.D. Kjær, A. Trabucco, J.K. Hansen, W.H. Maes, L. Graudal, F.K. Akinnifesi, B. Muys. 2010. Towards domestication of Jatropha curcas. Biofuels 1:91107.

Bhattacharya, A., K. Datta, S.K. Datta. 2005. Floral biology, floral resource constraints and pollination limitation in Jatropha curcas L. Pak. J. Bio. Sci. 8:456-60.

Bibi, N., K. Fan, S. Yuan, M. Ni, I.M. Ahmed, W. Malik, X. Wang. 2013. An efficient and highly reproducible approach for the selection of upland transgenic cotton produced by pollen tube pathway method. Austr. J. Crop Sci. 7:1714-1722.

Chen, T., S. Wu, J. Zhao, W. Guo, T. Zhang. 2010. Pistil drip following pollination: A simple in planta Agrobacterium-mediated transformation in cotton. Biotech. Lett. 32:547-555.
Cholid, M. 2014. Potensi jarak pagar (Jatropha curcas L.) sebagai tanaman pengendali erosi. Info-Tekbun. $6: 25-28$.

Daud, M.K., M.T. Variath, S. Ali, M. Jamil, M.T. Khan, M. Shafi, S. Zhu. 2009. Genetic transformation of Bar gene and its inheritance and segregation behavior in the resultant transgenic cotton germplasm (BR001). Pak. J. Bot. 41:2167-2178.

Divakara, B.N., H.D. Upadhyaya, S.P. Wani, C.L.L Gowda. 2009. Biology and genetic improvement of Jatropha curcas L.: A review. Appl. Energy 87:732-742.

Ghosh, L., L. Singh, 2011. Variation in seed and seedling characters of Jatropha curcas L with varying zones and provenances. Trop. Ecol. 52:113-122.

Gu, K., H. Mao, Z. Yin. 2014. Production of markerfree transgenic Jatropha curcas expressing hybrid Bacillus thuringiensis $\delta$-endotoxin $\mathrm{Cry} 1 \mathrm{Ab} / 1 \mathrm{Ac}$ for resistance to larvae of tortrix moth (Archips micaceanus). Biotech. for Biofuels 7:1-9.

Hartati, R.R.S, A. Setiawan, B. Heliyanto, Sudarsono. 2012. Keragaman genetik, heritabilitas, dan korelasi antar karakter 10 genotipe terpilih jarak pagar (Jatropha curcas L.). J. Littri 18:74-80.

Hasnam. 2006. Variasi Jatropha curcas L. Infotek Jarak Pagar 1:5-8.

Luo, Z.X., R. Wu. 1988. A simple method for the transformation of rice via the pollen tube pathway. Plant Mol. Bio. Rep. 6: 165-174.

Moncaleano-Escandon, J., B.C.F. Silva, S.R.S. Silva, J.A.A Granjab, M.C.J.L. Alvesc, M.F. Pompellib. 2013. Germination responses of Jatropha curcas L. seeds to storage and aging. Industrial Crops and Prod. 44:684-690.

Negussie, A., W.M.J. Achten, H.A.F. Verboven, M. Hermy, B. Muys. 2013. Floral display and effects of natural and artificial pollination on fruiting and seed yield of the tropical biofuel crop Jatropha curcas L. GCB. Bioenergy 1:1-9.

Nietsche, S., W.A. Vendrame, J.H. Crane, M.C.T. Pereira. 2014. Assessment of reproductive characteristics of Jatropha curcas L. in south Florida. GCB. Bioenergy 6:351-359.

Novita, L., N. Haska, M. Surahman, Y. Wahyu. 2014. Pendugaan parameter genetik karakter morfoagronomi dan seleksi genotipe untuk perbaikan genetik jarak pagar. J. Agron. Indonesia 42:236-243. 
Padonou, E.A., B. Kassa, A.E. Assogbadjo, B. Fandohan, S. Chakeredza, R.G. Kakaï, B. Sinsin. 2014. Natural variation in fruit characteristics and seed germination of Jatropha curcas in Benin, West Africa. J. Hort. Sci. Biotech. 89:69-73.

Pan, J., Q. Fu, ZF. Xu. 2010. Agrobacterium tumefaciensmediated transformation of biofuel plant Jatropha curcas using kanamycin selection. African J. Biotech. 9:6477-6481.

Parwata, I.G.M.A., D. Indradewa, P. Yudono, B.D. Kertonegoro, R. Kusmarwiyah. 2014. Respon pertumbuhan dan hasil tanaman jarak pagar (Jatropha curcas L.) terhadap cekaman kekeringan di lahan pasir pantai pada tahun pertama siklus produksi. J. Agron. Indonesia 42:59-65.

Pranesh, K.J., M.R.G. Rao, H.C. Sowmya, B. Gowda, D.L. Savithramma, N.L. Naveen. 2010. Studies on floral display and mode of reproduction in jatropha (Jatropha curcas L.). Electronic J. Plant Breed. 1:832-838.

Qu, J., H.Z. Mao, W. Chen, S.Q. Gao, Y.N. Bai, Y.W. Sun, Y.F. Geng, J. Ye. 2012. Development of marker-free transgenic Jatropha plants with increased levels of seed oleic acid. Biotech. Biofuels 5:1-11.

Shan, W., C. Zhao, J. Fan, H. Cong, S. Liang, X. Yu. 2012. Antisense suppression of alcohol acetyltransferase gene in ripening melon fruit alters volatile composition. Sci. Hort. 139:96-101.

Surahman, M., E. Santosa, F.N. Nisya. 2009. Karakterisasi dan analisis gerombol plasma nutfah jarak pagar Indonesia dan beberapa negara lain menggunakan marka morfologi dan molekuler. J. Agron. Indonesia 37:256-264.

Tistama, R. 2012. Isolasi dan introduksi gen sitrat sintase dari Pseudomonas aeruginosa ke dalam tanaman untuk meningkatkan toleransi terhadap cekaman aluminium. Disertasi. Sekolah Pascasarjana. Institut Pertanian Bogor. Bogor.

Wang, W., J. Wang, C. Yang, Y. Li, L. Liu, J. Xu. 2007. Pollen-mediated transformation of Sorghum bicolor plants. Biotechnol. Appl. Biochem. 48:79-83.
Wang, X., B. Liu, C. Huang, X. Zhang, C. Luo, X. Cheng, R. Yu, Z. Wu. 2012. Over expression of Zmda1-1 gene increases seed mass of corn. African J. Biotech. 11:13387-13395.

Wang, X.R., G.J. Ding. 2012. Reproductive biology characteristic of Jatropha curcas (Euphorbiaceae). Rev. Biol. Trop. 60:1525-1533.

Wilson, A.K., J.R. Latham, R.A. Steinbrecher. 2006. Tansformation-induced mutations in transgenic plants: Analysis and biosafety implications. Biotech. Genet. Engineering Rev. 23:209-234.

Yang, A., Q. Su, L. An. 2009. Ovary-drip transformation: A simple method for directly generating vector- and marker-free transgenic maize (Zea mays L.) with a linear GFP cassette transformation. Planta 229:793801 .

Yang. S., G. Li, M. Li, J. Wang. 2011. Transgenic soybean with low phytate content constructed by agrobacterium transformation and pollen-tube pathway. Euphytica 177:375-382.

Ye, M., C. Li, G. Francis, H.P.S. Makkar. 2009. Current situation and prospects of Jatropha curcas as a multipurpose tree in China. Agroforest. Syst. 76:487497.

Zale, J.M., S. Agarwal, S. Loar, C.M. Steber. 2009. Evidence for stable transformation of wheat by floral dip in Agrobacterium tumefaciens. Plant Cell Rep. 28:903913.

Zhang, H., F. Zhao, Y. Zhao, C. Guo, C. Li, K. Xiao. 2009. Establishment of transgenic cotton lines with high efficiency via pollen-tube pathway. Front. Agric. China 3:359-365.

Zhang, W., L. Jin, X. Li, X. Jiang, Y. Wang, X. Wang. 2012. Grain quality evaluations of hybrids between Triticum aestivum and Sorghum bicolor produced by pollen tube pathway method. Aust. J. Crop. Sci. 6:1712-1717. 